\title{
Redescription and biological aspects of Hormathia alba (Andres, 1881), a luminescent sea anemone (Anthozoa, Actiniaria)
}

\author{
J. M. Tur \\ Centre d'Estudis Avançats de Blanes; Camí de Sta. Bàrbara, 17300 Blanes (Girona), \\ Spain
}

\begin{abstract}
The sea anemone Hormathia alba (Andres, 1881) is redescribed and definitely established as distinct from $H$. coronata. Synonymy, external morphology, anatomy and cnidom are treated in detail. Aspects of its reproduction, ecology, distribution and distinctive characteristics are also reported. The species, largely mistaken throughout literature, is rather common on Mediterranean infralittoral soft bottoms. It has also been found in the SW of Ireland. This is the only known sea anemone with luminescence, a feature that has never been reported before.
\end{abstract}

\section{INTRODUCTION}

Hormathia coronata (Gosse, 1858) is a common sea anemone in coastal detritic bottoms of the North Atlantic and western Mediterranean. Hormathia alba (Andres, 1881) has a similar geographical distribution as that of $H$. coronata, but lives in deeper waters. Both are reported as a single species in the main revisions of Mediterranean sea anemones (Andres, 1881, 1884; Schmidt, 1972) and no mention of $H$. alba is found in the works referring to North Atlantic species.

The examination of living specimens of $H$. alba from the Catalan sea, with anatomical investigations and analysis of the cnidom, have evidenced that this species is clearly different from $H$. coronata.

\section{MATERIAL AND METHODS}

From 1981 to 1986 fifty-three specimens collected by trawlers in Blanes (NE of Spain) were observed in an aquarium for several weeks. The specimens were anaesthetized with menthol (sea water over-saturated solution) and preserved first in $10 \%$ formalin for a week, and secondly in $5 \%$ formalin for two weeks, before being stored in $70 \%$ ethanol. Twelve animals were dissected, stained with polychrome methylene blue and rinsed in freshwater, before being examined through stereo microscopy. Cnidom was observed and measured under phase contrast, in six specimens, from living tissues crushed in distilled water. Ten sets of measures were taken for each type of capsule present in five types of tissues. 


\section{DESCRIPTION}

\section{Genus Hormathia Gosse, 1859, p. 47}

Hormathiidae with well-developed base. Column differentiated into scapus and scapulus, the former with tubercles more or less arranged in rows, sometimes reduced. Periderm covering the whole scapus, or restricted to patches. Usually not more than 96 tentacles. Same number of mesenteries proximally as distally. Longitudinal musculature of tentacles and radial musculature of disc ectodermal, or the latter partly mesogloeal. Two well-developed siphonoglyphs. Six pairs of perfect and sterile mesenteries. Retractors diffuse (Carlgren, 1949, p. 92, modified).

\section{Hormathia alba (Andres, 1881), p. 326}

Sy n o n y m. Phellia nummus var. alba Andres, 1881, p. 326; Phelliopsis nummus Fischer, 1887, p.410; Hormathia mediterranea Carlgren, 1935, p.4; Paracalliactis mediterranea Ross \& Zamponi, 1982, p. 176.

Description of an individual. Size: $\varnothing$ base, $2.5 \mathrm{~cm} ; \varnothing$ disc and tentacles, $3.0 \mathrm{~cm}$; height, $2.6 \mathrm{~cm}$.

Base: Firmly adherent, larger than the column; limbus slightly notched by the mesenterial insertions. Ground colour white, with mesenterial insertions visible as radial lines.

Column: Pillar-like, widening towards the base and very flat in contraction. Division into scapus and scapulus not clearly marked. Scapus with tubercles longitudinally and transversely arranged, and an easily shed periderm, which often only remains in the proximal part, or is distributed in patches. Tubercles may not be conspicuous but are always distinct to the touch. Scapulus smooth and naked (Fig. 1B). Substance hardening in contraction, becoming softer and translucent in expansion. Margin tentaculate, but in little contracted specimens a small fosse is visible. The colour beneath the periderm is pure white, with pinkish shades in the scapulus.

Tentacles: $96(6,6,12,24,48)$, small, somewhat conical, with rather blunt tips, the inner ones longer that the outer ones. Translucent, orange-pink, with a more vivid stripe at the base, larger on the aboral face, and a white spot connecting with each radius in the oral face. This spot is very small in the two first circles.

Disc: Circular, somewhat convex. Directive radii almost indistinct, lip thin. Peristome with an inner circle of white spots and lines, a conspicuous medium and an outer circle, yellow in colour, corresponding with radii and mesenterial insertions. Actinopharynx cream, with several brown longitudinal ridges, characteristic of the species (Fig. 1A). Siphonoglyphs also brown. Ground colour hyalin white.

Col our variation. Sometimes there are two longitudinal, pinkish-salmon lines running along the sides of the tentacles, from base to tip. Although the medium circle of spots of the peristome is characteristic of the species, its colour varies from white to yellow, or orange-pink. The 12 spots of this medium circle are subdivided into small ones in large specimens.

A n a t o my. In the specimens studied there were 4 circles of mesenteries, sometimes signs of a fifth. Six pairs were perfect, including 2 pairs of directives attached to 2 

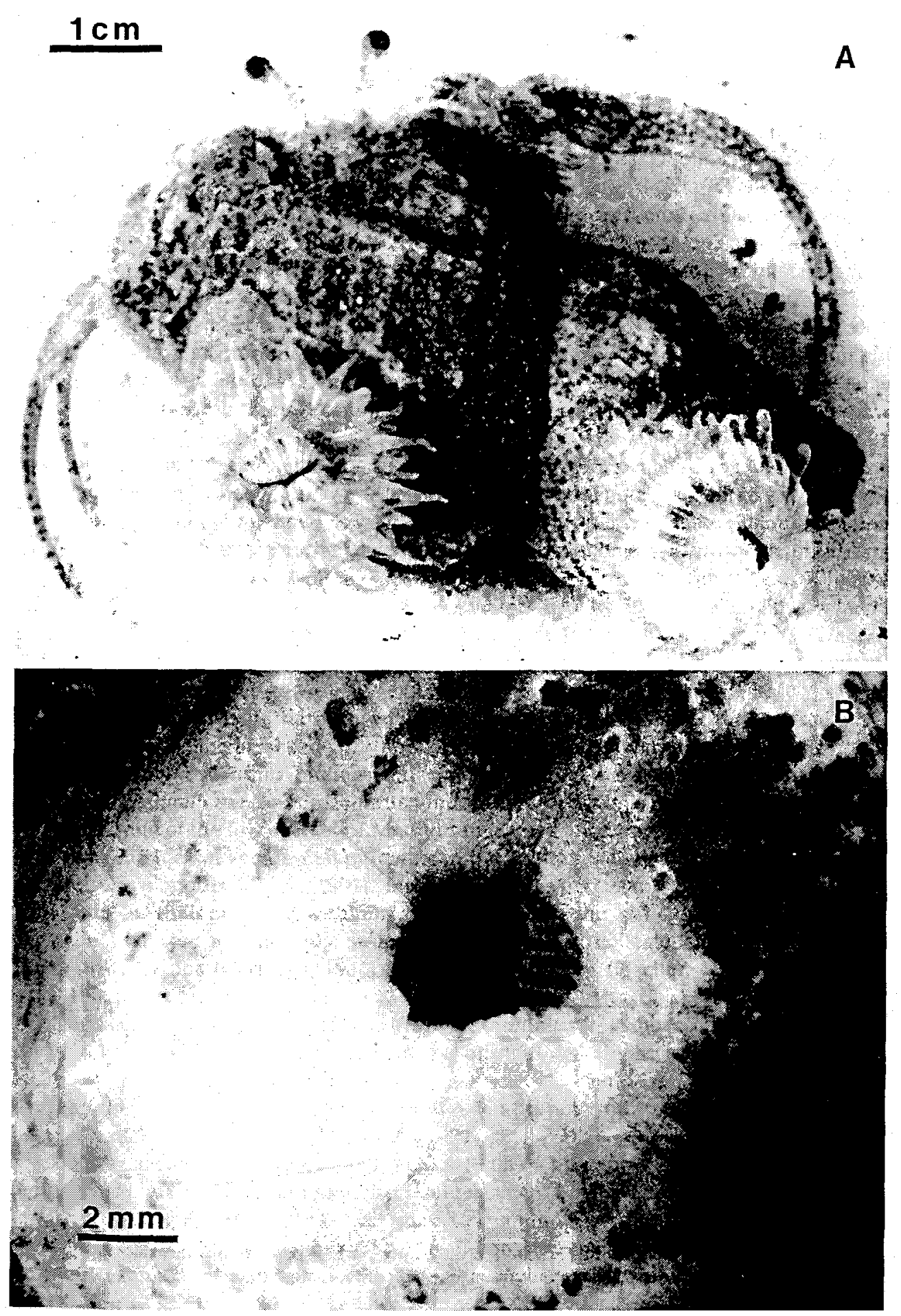

Fig. 1. Hormathia alba. A: expanded specimens on a shell inhabited by Pagurus variabilis. B; smooth distal part of the column in a contracted specimen 
siphonoglyphs, bearing oral stoma but not parietal stoma. Gonads were present on the mesenteries of circles 2-4, mainly at the level of ciliated tracts, and acontia on the mesenteries of circles 1-4. The retractor muscles were not very developed, diffuse or diffuse circumscript, with the parietobasilar muscles indistinctly marked. The sphincter was separated from the endoderm by a band of mesogloea; it was strongly developed and diffuse, with a somewhat truncated basal part and very well-developed longitudinal muscle-meshes (Fig. 2). Basilar muscles were slightly developed, and radial muscles of disc and longitudinal muscles of tentacles were meso-ectodermal.

Cnidom. This is typical of the Hormathiidae (Carlgren, 1949, p. 91): Spirocysts, basitrichs and microbasic p-mastigophores.

Basitrichs of the small size (Table 1) and the mastigophores of the actinopharynx are uncommon. There are actually two different types of microbasic p-mastigophores in the filaments, one somewhat longer than the other, and with a shorter shaft - the short type usually forming darts. In one of the specimens examined, additional p-mastigophores were present in the scapus, as is usually the case in other Hormathia (Riemann-Zürneck, 1973; den Hartog, 1977).

Re prod u cti o n. Hormathia alba is dioecious and oviparous. No larvae have been found in any of the specimens collected throughout the year. Gonads are developed from early autumn. Several specimens sampled in February showed partly empty gonadal sacs and large mature oocytes; this suggests that sexual products may be released during winter.

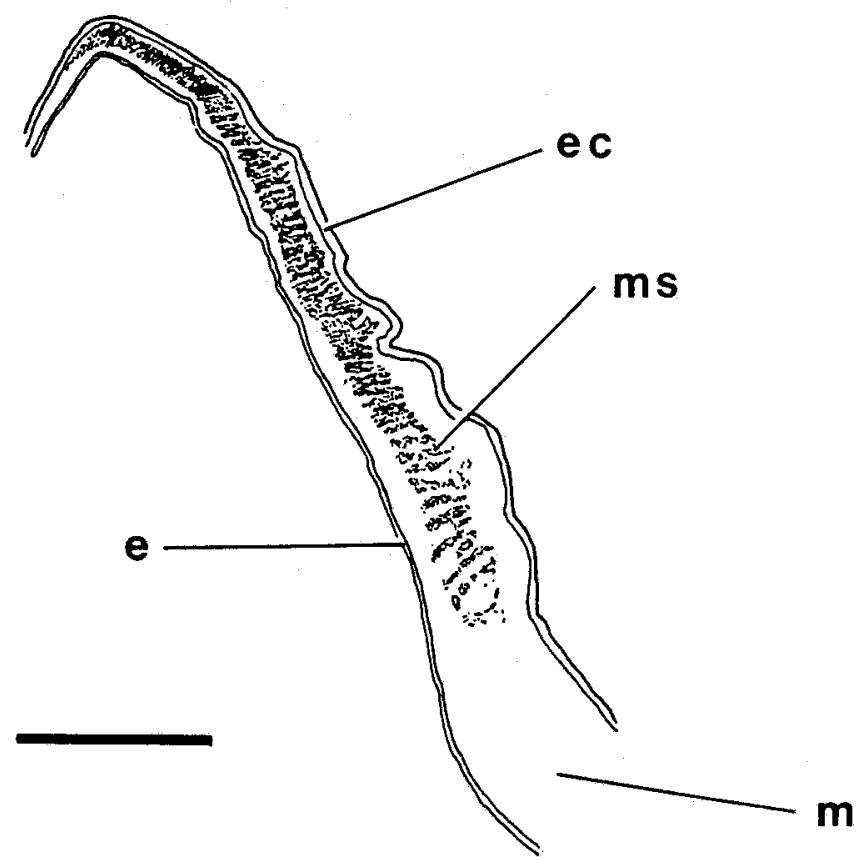

Fig. 2. Hormathia alba. Longitudinal section of the upper part of the column, showing the sphincter muscle; e: endoderm, ec: ectoderm, m: mesogloea, ms: muscle meshes. Bar, $1 \mathrm{~mm}$ 
Table 1. Size and distribution of nematocysts of Hormathia alba

\begin{tabular}{|lll|}
\hline Body region & Nematocyst & Average and range $(\mu \mathrm{m})$ \\
\hline Column (Scapus) & Basitrichs & $24.9(12.8-32.0) \times 3.3(2.5-4.5)$ \\
Tentacles & Spirocysts & $31.2(18.7-48.0) \times 4.6(2.6-6.5)$ \\
& Basitrichs & $20.6(17.0-24.0) \times 2.6(2.0-3.5)$ \\
Actinopharynx & Basitrichs I & $13.1(11.0-14.2) \times 1.6(1.5-1.8)$ \\
& Basitrichs II & $26.8(22.0-30.0) \times 2.5(2.0-3.1)$ \\
Filaments & p-mastigoph. & $27.9(23.0-30.1) \times 4.4(3.0-5.0)$ \\
& Basitrichs & $11.6(10.0-18.0) \times 1.6(1.5-2.0)$ \\
Acontia & p-mastigoph. & $26.5(24.0-30.5) \times 3.9(2.5-5.0)$ \\
& Basitrichs & $28.7(26.8-30.1) \times 3.6(3.0-4.0)$ \\
\hline
\end{tabular}

Ecological notes. The species has been collected from 70 to $700 \mathrm{~m}$ depth on coastal detritic and muddy bottoms. Is is not uncommon to find it attached to Pinna pectinata L., Microcosmus vulgaris Heller, and to shells of several gastropoda (Galeodea, Semicassis, Buccinum, Aporrhais etc.) inhabited by Dardanus arrosor (Hebst), Pagurus variabilis Milne-Edwards \& Bouvier, Pagurus alatus Fabricius, and even Pagurus prideauxii Leach. Specimens from shallower waters usually share shells with Calliactis parasitica (Couch), and sometimes Adamsia palliata (Bohadsh) and Sagartia elegans (Dalyell). H. alba is also found living in muddy bottoms with Funiculina quadrangularis (Pallas).

Hormathia alba is, to date, the only known species of luminescent sea anemone. Luminescence is not localized and appears to be extracellular; its function is totally unknown. Only two other luminescent species among the Hexacorallia are known: Parazoanthus lucificum and Epizoanthus induratum (reviewed by Morin, 1974).

This is one of the few species of Mediterranean sea anemones that do not live well in captivity. The lack of ectodermal pigments in the column wall, acting as screens against harmful wavelengths (Shick, 1991), may make it less resistant. Specimens put in an aquarium lose their periderm within a few weeks, lacerating and dying after 2-4 months.

Distribution. The species has previously been collected at Naples (Andres, 1881, 1884), Genoa (Carlgren, 1935) and Banyuls-sur-Mer (Fischer, 1887; Ross \& Zamponi, 1982). It is also present on the SW coast of Ireland (pers. obs.).

The record by Nobre (1931: 45) of Phellia nummus from Buarcos (Portugal) seems very likely to refer to $H$. coronata, since no original description was supplied and the author did not mention this species in the area where it would be expected to be found. On the other hand, in the area considered in the present study, $H$. alba has previously been recorded as $H$. coronata (Gili et al., 1987).

Distinctive characteristics of the species. The most distinctive feature of $H$. alba is, undoubtedly, the luminescence. This can be detected as a bluish, luminous slime originating in the coelenteron, after gentle pressure on the columnar wall.

Moreover, the white colour of the column beneath the periderm, the poorly developed tubercles and the smooth, pinkish scapulus, allow this species to be disting- 
uished from the remaining Mediterranean ones. In addition, the nematocysts of the acontia are shorter and thicker than those of $H$. coronata, the sphincter is longer, and the retractor muscles more developed in $H$. alba. Furthermore, $H$. coronata has a thicker periderm and well-developed coronal tubercles, with very characteristic brown marks between them. Finally, $H$. alba is always oviparous, whereas $H$. coronata is usually viviparous.

\section{DISCUSSION}

The description of Phellia nummus by Andres (1881) included four varieties; two of these, var. lutea and var. badia, actually refer to Hormathia coronata, while var. alba and var. rufa belong to a different species. The same author later described (1884) six different varieties, trying to set up a series of gradual pigmentation. In fact, both species show a considerable degree of variation in colour, even if a basic pattern is ascribable to each. On the other hand, Fischer (1887, p. 412) had already pointed out the existing differences between $H$. coronata and $P$. (Phelliopsis) nummus. Moreover, the author was surprised that no report of $H$. coronata in the Mediterranean had been previously recorded.

From a collection of sea anemones from the Gulf of Genoa, Carlgren (1935) distinguished several specimens of a species he believed to be different from $H$. coronata, and reported them as Hormathia mediterranea. Schmidt (1972, pp. 29, 32) - arguing that Andres $(1881,1884)$ did not mention $H$. coronata in Neapel - identified $P$. nummus with $H$. coronata. Furthermore, this author considered $H$. mediterranea to be identical with $H$. coronata, and the differences observed by Carlgren imputable to intraspecific variation.

More recently, Ross \& Zamponi (1982) described the species as Paracalliactis mediterranea. The genus Paracalliactis has a deformed base bearing a cuticle, and a smooth scapus (Carlgren, 1945, p. 94), and this is not the case in the specimens described by those authors. Moreover, Carlgren's description included an account of cnidom with categories of nematocysts never found together in any existing species of sea anemone. Ross \& Zamponi have misinterpreted different stages of development as distinct categories of nematocysts; these stages are frequent in specimens maintained in artificial conditions for several weeks, as was the case of those on which the description was based.

According to I.C.Z.N. (Art. $10 \mathrm{c}$ and $45 \mathrm{~g}$ ), Hormathia alba is a valid name for Phellia nummus var. alba Andres, 1881. $H$. nummus would not be valid because it includes two different species.

Acknowledgements. The author thanks Dr. M. Uriz and Dr. R. Sardá for their reading of the manuscript.

\section{LITERATURE CITED}

Andres, A., 1881. Prodromus neapolitanae actiniarum faunae. - Mitt. zool. Stn Neapel 2, 305-317.

Andres, A., 1884. Le attinie. - Fauna u. Flora Golf. Neapel 9 (1), 1-459.

Carlgren, O., 1935. Di alcune Attinie e Zoantari raccolti nel Golfo di Genova. - Boll. Musei Lab. Zool. Anat. comp. R. Univ. Genova 15 (83), 3-13.

Carlgren, O., 1949. A survey of the Ptychodactiaria, Corallimorpharia and Actiniaria. - K. svenska VetenskAkad. Handl. (Ser. 4) 1, 1-121.

Fischer, P., 1887. Contribution à l'actinologie française. - Archs Zool. exp. gén. (Sér. 2) 5, 381-442. 
Gili, J. M., Ros, J. D. \& Pagès, F., 1987. Types of bottoms and benthic Cnidaria from the trawling grounds (littoral and bathyal) off Catalonia (NE Spain). - Vie Milieu 37, 85-98.

Gosse, P. H., 1858. Characters and Descriptions of some new British Sea Anemones. - Ann. Mag. nat. Hist. 2 (3), 192-196.

Gosse, P. H., 1859. Characters and Descriptions of some new British Sea Anemones. - Ann. Mag. nat. Hist. 3 (3), 46-50.

Hartog den, J. C., 1977. Notes on the little known sea anemone Cataphellia brodricii and on the closely allied Hormathia coronata and Paraphellia expansa (Actiniaria, Hormathiidae). - Neth. J. Zool. 27, 237-244.

International Commission on Zoological Nomenclature, 1985. International code of zoological nomenclature. Univ. of California Press, Berkeley, $338 \mathrm{pp}$.

Morin, J. G., 1974. Coelenterate bioluminescence. In: Coelenterate biology. Reviews and new perspectives. Ed. by L. Muscatine \& H. M. Lenhoff. Acad. Press, New York, $397-438$.

Nobre, A., 1931. Contribuiçōes para o estudo dos Coelenterados de Portugal. Instituto de Zoologia da Universidade do Pôrto. Impr. portuguesa, Pôrto, $82 \mathrm{pp}$.

Riemann-Zürneck, K., 1973. Actiniaria des Südwestatlantik. I. Hormathiidae. - Helgoländer Meeresunters. 25, 273-325.

Ross, D. M. \& Zamponi, M. O., 1982. A symbiosis between Paracalliactis mediterranea n. sp. (Ant. Act.) and Pagurus variabilis M. Edwards \& Bouvier. - Vie Milieu 32, 175-181.

Schmidt, H., 1972. Prodromus zu einer Monographie der mediterranen Aktinien. - Zoologica, Stuttg. 42, Lfg 2 (121), 1-146.

Shick, J. M., 1991. A functional biology of sea anemones. Chapman \& Hall, London, $395 \mathrm{pp.}$ 